\title{
Effects of ginsenoside Rg1 on the senescence of vascular smooth muscle cells
}

\author{
S.G. Li, M.Z. Yan, D. Zhang, M. Ye and J.J. Deng \\ Department of Geriatrics, The First College of Clinical Medical Science, \\ China Three Gorges University, Yichang Central People's Hospital, Yichang, \\ Hubei, China \\ Corresponding author: S.G. Li \\ E-mail: shuguolicn@126.com
}

Genet. Mol. Res. 15 (3): gmr.15038409

Received January 8, 2016

Accepted May 24, 2016

Published September 2, 2016

DOI http://dx.doi.org/10.4238/gmr.15038409

Copyright $(C 2016$ The Authors. This is an open-access article distributed under the terms of the Creative Commons Attribution ShareAlike (CC BY-SA) 4.0 License.

ABSTRACT. The development of age-related cardiovascular disease
is associated with the senescence of vascular cells. This study aimed
to investigate the effect of ginsenoside Rg1 on vascular smooth
muscle cell (VSMC) senescence. Primary VSMCs were cultured and
divided into control, D-galactose (D-gal), Rg1-L, and Rg1-H groups,
which were cultured without and with D-gal, and with low- and high-
concentrations of Rg1, respectively. D-gal-induced cellular senescence
was identified by $\beta$-galactosidase staining, and ultrastructural changes
within the cells were observed. The expression of p16, p21, and p53
in the four groups of VSMCs was determined by western blotting,
and the cell cycle was investigated by flow cytometry. Compared with
the control group, there was an obvious change in the ultrastructure
of VSMCs in the D-gal group, and the proportion of $\beta$-galactosidase-
positive cells was significantly increased (P $<0.05)$. In addition, p16,
p21, and p53 expression was significantly increased $(\mathrm{P}<0.05)$ and the
cell cycle was arrested in the G0/G1 phase. Compared with the D-gal

Genetics and Molecular Research 15 (3): gmr.15038409 
group, the percentage of positive cells was significantly reduced $(\mathrm{P}<0.05)$ in the $\mathrm{Rg} 1$ groups, the expression of $\mathrm{p} 16, \mathrm{p} 21$, and $\mathrm{p} 53$ was significantly reduced $(\mathrm{P}<0.05)$, and the number of cells in the $\mathrm{G} 0 / \mathrm{G} 1$ phase decreased $(\mathrm{P}<0.05)$. Ginsenoside Rg1 can inhibit VSMC senescence, and the mechanisms may be related to its partial inhibition of the $\mathrm{p} 16^{\mathrm{INK} 4 a} / \mathrm{Rb}$ and p53-p2 $1^{\text {Cip } 1 / \text { Wafl }}$ signaling pathways during the cell cycle.

Key words: Vascular smooth muscle cells; Senescence; Ginsenoside Rg1; Signaling pathway

\section{INTRODUCTION}

Biological ageing and associated chronic diseases are areas of intense research. Ageing occurs as a result of cellular senescence, and the occurrence and development of age-related cardiovascular diseases are associated with the senescence of vascular cells (Cheung et al., 2015). Cell senescence is a complex pathophysiological process, which involves multiple factors regulated by the cell cycle. A key feature of senescence is cell-cycle arrest. The mechanisms responsible for cellular senescence include oxygen-free radicals, telomere shortening, gene senescence, DNA damage, intermolecular crosslinking, inflammatory cytokines, and metabolism (Xi et al., 2013; Tian, 2014). Cell senescence can be divided into two categories, namely selfrepeating senescence and stress-induced premature senescence. The former is mainly caused by telomere shortening or dysfunction, while the latter is mainly induced by $\mathrm{H}_{2} \mathrm{O}_{2}$ and ultraviolet, which arrest the cell cycle during the G1 phase (Sikora et al., 2011; Bianchessi et al., 2015). Mechanisms in both categories are involved in congenerous molecular signaling transduction pathways, such as the p16 ${ }^{\mathrm{INK} 4 a} / \mathrm{Rb}$ and $\mathrm{p} 53$-p2 $1^{\text {Cipl/Wafl }}$ pathways (Beauséjour et al., 2003; Krishnamurthy et al., 2004). Further study on the biological mechanisms of cell senescence, on methods of delaying senescence, and into senescence-targeted drugs may be important for preventing and treating cardiovascular diseases associated with ageing.

Ginsenosides are the main active components of ginseng, and have a wide range of medicinal uses. Studies have shown that ginsenoside exerts anti-inflammatory, anti-oxidant, and anti-senescent effects, and is involved in heart and brain blood vessel protection, and memory improvement (Wang et al., 2010; Li et al., 2014). Ginsenoside Rg1 can also treat and delay t-BHPinduced neural stem cell senescence, and the mechanism is associated with the $\mathrm{p} 16^{\mathrm{INK} 4 \mathrm{a}} / \mathrm{Rb}$ and p19 Arf-Mdm2-p53-p21 $1^{\text {Cipl/Wafl }}$ signaling pathways (Yue et al., 2014). Vascular smooth muscle cell (VSMC) senescence plays an important role in the pathogenesis of atherosclerosis (Gorenne et al., 2006). In this study, the effect of ginsenoside Rg1 on VSMC senescence was investigated, and the related mechanisms were explored. The objective of this study was to provide a basis for the application of ginsenoside to the treatment of age-related cardiovascular diseases.

\section{MATERIAL AND METHODS}

\section{Culture of rat VSMCs}

This study was conducted with approval from the Animal Ethics Committee of The First College of Clinical Medical Science, China Three Gorges University. Six male SpragueDawley (SD) rats (150-180 g, provided by the Experimental Animal Center of China Three

Genetics and Molecular Research 15 (3): gmr.15038409 
Gorges University, Yichang, China) were anesthetized with $10 \%$ chloral hydrate, and the thoracic aorta was subsequently isolated under sterile conditions. Following the removal of the connective tissues, the blood vessels were longitudinally dissected, and the tunica externa and tunica intima were peeled. The tunica media was cut into $1-2-\mathrm{mm}^{2}$ tissue masses. The wall-adherence method was used to culture VSMCs in $20 \%$ fetal bovine serum-containing Dulbecco's modified Eagle's medium (DMEM) (Fuzhou Maixin Biotechnology Development Co., Ltd., Fuzhou, China) at $37^{\circ} \mathrm{C}$ and $5 \% \mathrm{CO}_{2}$. Subcultures were performed once the cells reached confluence. VSMCs with purity exceeding $98 \%$ were obtained, and the 3rd to 6th generations of cells were used for subsequent experiments.

\section{Grouping and treatment}

VSMCs were randomly divided into a control group, a D-galactose (D-gal) group, an Rg1-L group, and an Rg1-H group. The control group was cultured in DMEM without D-gal. The D-gal group was cultured in DMEM containing $10 \mathrm{~g} / \mathrm{L}$ D-gal. The Rg1-L group was cultured in low concentrations of Rg1 (10 g/L D-gal + $10 \mu \mathrm{M}$ ginsenoside Rg1). The Rg1-H group was cultured in high concentrations of $\mathrm{Rg} 1(10 \mathrm{~g} / \mathrm{L} \mathrm{D}$-gal $+20 \mu \mathrm{M}$ ginsenoside $\mathrm{Rg} 1)$. Each group was cultured for $48 \mathrm{~h}$. All regents were provided by Fuzhou Maixin Biotechnology Development Co., Ltd.

\section{$\beta$-galactosidase staining}

Cellular senescence was detected by $\beta$-galactosidase staining using a kit in accordance with the manufacturer instructions (Shanghai Genmed Gene Pharmaceutical Technology Co., Ltd., Shanghai, China). VSMCs were cultured on 24-well plates, and then the medium was removed. $\beta$-galactosidase-staining fixative was added at room temperature and cells were fixed for $5 \mathrm{~min}$. Citrate buffer, pH 6.0, was added to each well. After $10 \mathrm{~min}$, the buffer was removed, the preheated staining solution was added to each well, and cells were cultured for $3-16 \mathrm{~h}\left(37^{\circ} \mathrm{C}, \mathrm{CO}_{2}\right.$ free $)$. The cells were observed and photographed under a DVM6 optical microscope (Leica Science Lab., Berlin, Germany), and all blue-stained cells (positive cells) were counted. Three vision fields were randomly selected, and 100 cells were counted to calculate the senescence rate [senescence rate $(\%)=$ positive senescent cells $/ 100$ cells $\mathrm{x}$ $100 \%$ ]. Each experiment was repeated five times.

\section{Observation of cell ultrastructure}

VSMCs were digested and collected. After centrifuging at $352 \mathrm{~g}$ for $10 \mathrm{~min}$, the supernatant was discarded. The cells were washed with pre-cooled PBS (Sigma-Aldrich Corp., St. Louis, MO, USA) once, and then fixed in $2.5 \%$ glutaraldehyde (Sigma-Aldrich Corp.) and $1 \%$ osmium tetroxide (Sigma-Aldrich Corp.) for $20 \mathrm{~min}$, respectively. After dehydrating through a gradient ethanol series and embedding in resin, tissue sections were obtained by slicing, and the ultrastructure of cells was observed under transmission electron microscope (Olympus Corp., Tokyo, Japan).

\section{Detection of p16, p21, and p53 protein expression}

Protein expression of $\mathrm{p} 16, \mathrm{p} 21$, and $\mathrm{p} 53$ was detected by western blotting. Total protein

Genetics and Molecular Research 15 (3): gmr.15038409 
was extracted from VSMCs using the radioimmunoprecipitation assay, and the protein concentration was measured using the bicinchoninic acid method. The extracted proteins were denatured by boiling for $5 \mathrm{~min}$. Next, $50 \mu \mathrm{g}$ of each protein sample was added to the loading buffer, and 10\% SDS-polyacrylamide gel electrophoresis was performed. Samples were then transferred to a membrane for $2 \mathrm{~h}$ and subsequently incubated in $5 \%$ skimmed milk for more $2 \mathrm{~h}$. Primary antibodies specific for $\mathrm{p} 16, \mathrm{p} 21, \mathrm{p} 53$, and $\beta$-actin (Santa Cruz Biotechnology, Inc., Dallas, TX, USA) were added, followed by culturing at $4^{\circ} \mathrm{C}$ overnight. Secondary antibody (goat anti-mouse IgG-HRP antibody; Santa Cruz Biotechnology, Inc.) was then added, followed by culturing at room temperature for $1 \mathrm{~h}$. Once developed, protein bands were observed and photographed using a Q550CW image acquisition and analysis system (Leica Science Lab.).

\section{Determination of cell cycle}

VSMCs were digested using $0.25 \%$ trypsin (Sigma-Aldrich Corp.), and then washed with PBS. The cells were re-suspended in $1 \mathrm{~mL}$ cell fixation solution ( $80 \%$ ethanol + 0.5 mM EDTA-containing PBS; Fuzhou Maixin Biotechnology Development Co., Ltd.), and fixed at $4^{\circ} \mathrm{C}$ for $30 \mathrm{~min}$. After centrifuging at $157 \mathrm{~g}$ for $5 \mathrm{~min}$, the supernatant was discarded. After washing with PBS, the cells were re-suspended in $500 \mu \mathrm{L}$ cell membrane perforation solution $(0.1 \%$ Triton X-100 $+50 \mu \mathrm{g} / \mathrm{mL}$ RNase-containing PBS; Fuzhou Maixin Biotechnology Development Co., Ltd.). Then, $90 \mu \mathrm{L} 0.5 \mathrm{mg} / \mathrm{mL}$ propidium iodide (Fermentas Inc., USA) was added, followed by culturing at $37^{\circ} \mathrm{C}$ in darkness for 30 min. After being filtered through a nylon membrane (Sigma-Aldrich Corp., MO, USA) the cells were analyzed using a FACSCanto ${ }^{\mathrm{TM}}$ II flow cytometry (Becton, Dickinson and Company, USA).

\section{Statistical analysis}

Statistical analyses were carried out using the SPSS17.0 software (SPSS Inc., Chicago, IL, USA). Data are reported as means \pm SD. Comparisons between groups were performed using the $t$-test. $\mathrm{P}<0.05$ was considered as statistically significant.

\section{RESULTS}

\section{$\beta$-galactosidase staining}

After $\beta$-galactosidase staining, only a few $\beta$-galactosidase-positive cells were observed in the control group, while the D-gal group exhibited a higher number of positively stained cells. Compared with the D-gal group, the Rg1 treatment groups exhibited fewer positive cells, with the highest number observed in the $\mathrm{Rg} 1-\mathrm{H}$ group (Figure 1). Cell counting revealed that $4.67 \pm 0.58 \%$ cells in the control group stained positive, and $58.67 \pm 2.52 \%$ cells in the D-gal group stained positive $(\mathrm{P}<0.05, \mathrm{~N}=5)$. This indicates that $\mathrm{D}$-gal can promote the senescence of VSMCs. The proportions of positively stained cells in the Rg1-L and Rg1-H groups were $34.67 \pm 1.53$ and $23.33 \pm 1.53 \%$, respectively, which were significantly lower than the values observed in the D-gal group $(\mathrm{P}<0.05, \mathrm{~N}=5)$ (Figure 2). This indicates that $\mathrm{Rg} 1$ can protect VSMCs from D-gal-induced senescence.

Genetics and Molecular Research 15 (3): gmr.15038409 


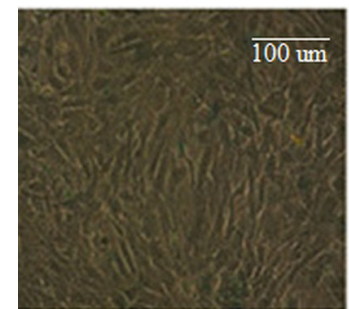

Control

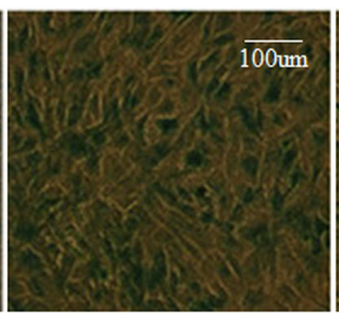

D-gal

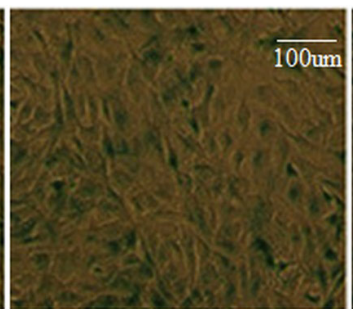

Rgl-L

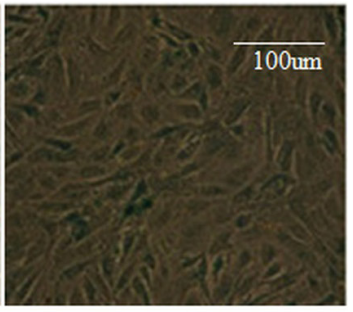

$\mathrm{Rgl-H}$

Figure 1. Results of $\beta$-galactosidase staining (200X).

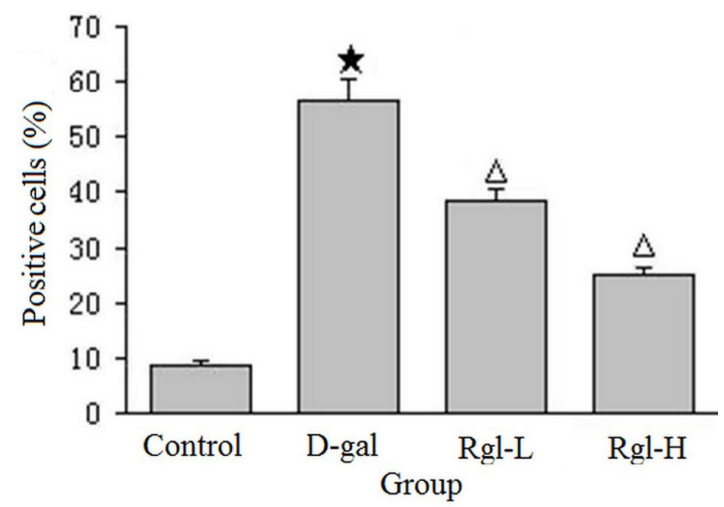

Figure 2. $\beta$-galactosidase-positive cells. ${ }^{\star} \mathrm{P}<0.05$ compared with control group; ${ }^{\wedge} \mathrm{P}<0.05$ compared with $\mathrm{D}$-gal group.

\section{Ultrastructural changes of VSMCs}

VSMCs in the control group exhibited a smooth nuclear membrane and normal mitochondrial structures, with no deposition of lipofuscin. In the D-gal group, VSMCs exhibited an inward-folded nuclear membrane and mitochondrial swelling with vacuolization, with a large amount of lipofuscin in the cytoplasm. This indicates that a model of VSMC senescence was successfully established (Figure 3).
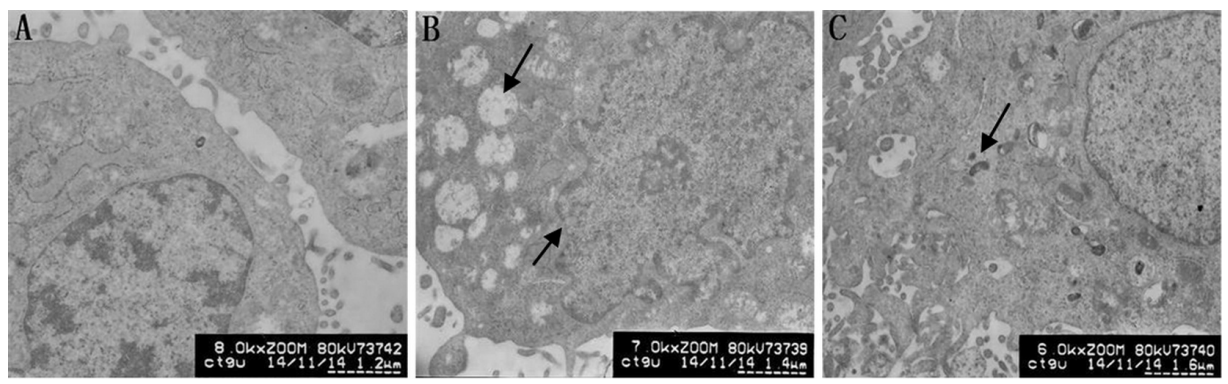

Figure 3. Ultrastructural changes of vascular smooth muscle cells (VSMCs). A. Control group (8000X); B. D-gal group, mitochondrial swelling (arrows), inward-folded nuclear membrane (7000X); C. D-gal group, deposition of lipofuscin (arrow, 6000X). 


\section{Effect of Rg1 on p16, p21, and p53 protein expression}

Compared with the control group, there was a significant $(\mathrm{P}<0.05)$ increase in the level of $\mathrm{p} 16, \mathrm{p} 21$, and 553 protein expression in VSMCs in the D-gal group. Compared with the D-gal group, protein expression was significantly $(\mathrm{P}<0.05)$, decreased in VSMCs in the $\operatorname{Rg} 1$ group with a further and more significant decrease observed in cells in the Rg1-H group (Figure 4).
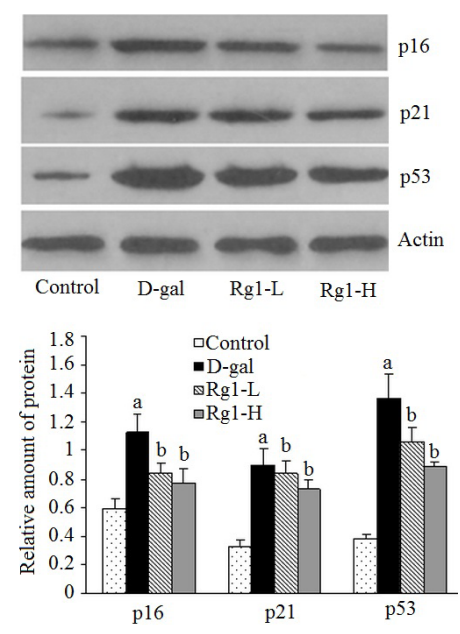

Figure 4. p16, p21, and p53 protein expression.

\section{Effect of ginsenoside Rg1 on cell cycle}

Compared with the control group, the number of VSMCs in the G0/G1 phase in the $D$-gal group was significantly increased $(P<0.05)$, while the number in the $S$ and $G 2 / M$ phases was significantly reduced $(\mathrm{P}<0.05)$. Compared with the $\mathrm{D}$-gal group, there were significantly $(\mathrm{P}<0.05)$, fewer VSMCs in the G0/G1 phase in the Rg1 treatment groups while the number of cells in the $\mathrm{S}$ and $\mathrm{G} 2 / \mathrm{M}$ phases was significantly increased. A more obvious increase was observed in VSMCs in the Rg1-H group (Figure 5 and Table 1).
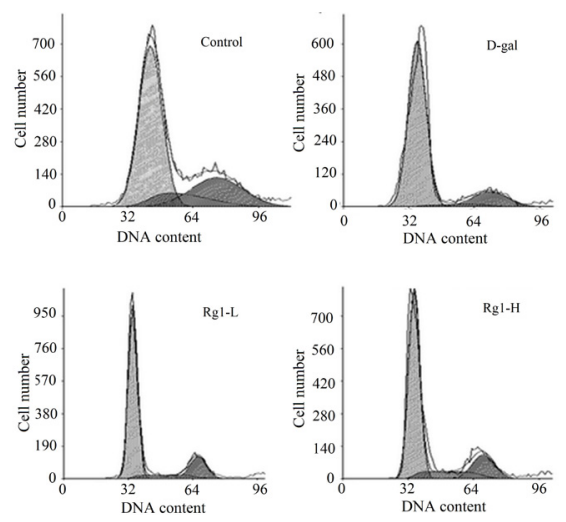

Figure 5. Effect of ginsenoside $\operatorname{Rg} 1$ on cell cycle.

Genetics and Molecular Research 15 (3): gmr.15038409 
Table 1. Effects of ginsenoside $\operatorname{Rg} 1$ on the cell cycle (means $\pm \mathrm{SD}, \mathrm{N}=5, \%$ ).

\begin{tabular}{l|c|c|c}
\hline Group & G0/G1 & S & G2/M \\
\hline Control & $60.50 \pm 0.10$ & $14.60 \pm 0.08$ & $24.90 \pm 0.09$ \\
\hline D-gal & $81.50 \pm 1.07^{*}$ & $3.80 \pm 0.11$ & $14.70 \pm 0.07^{*}$ \\
\hline Rg1-L & $74.30 \pm 0.72^{\Delta}$ & $7.80 \pm 0.26^{\Delta}$ & $17.90 \pm 0.82$ \\
\hline Rg1-H & $69.20 \pm 0.54^{\Delta}$ & $13.10 \pm 0.46^{\Delta}$ & $17.70 \pm 0.35$ \\
\hline
\end{tabular}

${ }^{*} \mathrm{P}<0.05$ compared with the control group; ${ }^{\Delta} \mathrm{P}<0.05$ compared with the $\mathrm{D}$-gal group.

\section{DISCUSSION}

A recent study reported that cellular senescence is induced by the activity of signaling transduction pathways, among which the $\mathrm{p} 16^{\mathrm{INK} 4 \mathrm{a}} / \mathrm{Rb}$ and $\mathrm{p} 53-\mathrm{p} 21^{\mathrm{Cip} 1 / \text { Wafl }}$ pathways are essential (Leontieva and Blagosklonny, 2013). p16, p21, and p53 are involved in regulating the cell cycle and, therefore, have important roles in the process of cellular senescence (Capparelli et al., 2012). p16 inhibits the binding of CDK4/6 and cyclinD, thus preventing the activation of $\mathrm{CDK} 4 / 6$, phosphorylation of $\mathrm{Rb}$, and the subsequent activation of the transcription factor E2F. Therefore, transcription cannot proceed normally and the cell cycle is arrested (LaPak and Burd, 2014). p16 plays a catalytic role in the senescence process of human diploid fibroblasts (Liu et al., 2001). p53 is an important transcriptional regulator and is unstable and expressed at low levels under normal circumstances. When DNA damage occurs, the level of p53 in the nucleus rapidly increases, thus inducing the expression of the downstream p21 gene, leading to the production of large amounts of $\mathrm{p} 21$ protein. In this way, the binding of CDK2 to cyclinE is inhibited, and $\mathrm{Rb}$ phosphorylation is prevented. E2f cannot be released, and the cell cycle is arrested in the G1 phase, permitting DNA damage to be repaired (Fenouille et al., 2011; Tane et al., 2014). In addition, p16 can increase the stability of p21, which can then induce the expression of the p16 gene via the transcription factor Spl. p16 and p21 can act synergistically to inhibit the cell cycle (Han et al., 2007).

Dimri et al. (1995) first proposed that $\beta$-galactosidase can be used as an in vivo biomarker to identify cell senescence. When cell senescence occurs, the increased level of intracellular $\beta$-galactosidase will degrade its substrate $\mathrm{X}$-gal at $\mathrm{pH}$ 6.0, which generates a blue product; this can be detected via histochemical staining (Debacq-Chainiaux et al., 2009). When establishing a model of senescence, D-gal has several advantages, including short modeling time, ease of use, and good reproducibility, and is therefore widely used in the study of senescence (Wen et al., 2005). However, reports on the use of D-gal in the development of senescence models in VSMCs are limited. In this study, D-gal was used to induce senescence in VSMCs. The results showed that, compared with the control group, the number of $\beta$-galpositive cells was increased upon D-gal-induction. Observation of the cellular ultrastructure revealed significant changes associated with senescence, including mitochondrial swelling, inward-folded nuclear membrane, and lipofuscin deposition. The expression of senescencerelated proteins increased, and the cell cycle was arrested in the G0/G1 phase. These findings indicate that D-gal can induce VSMC senescence and can be used to successfully establish an in vitro model of VSMC senescence.

As a precious Chinese medicine, research on ginseng goes back over 2000 years. Ginsenosides are the main effective components of ginseng, and have a wide range of pharmacological effects. This study showed that the ginsenoside Rg1 has effects on the senescence of VSMCs in response to D-gal treatment. The results show that ginsenoside

Genetics and Molecular Research 15 (3): gmr.15038409 
Rg1 can reduce the number of $\beta$-gal-positive cells, inhibit cellular senescence, reduce the expression of senescence-related proteins $\mathrm{p} 16, \mathrm{p} 21$, and $\mathrm{p} 53$, and reduce the length of the G0/ G1 phase of cell cycle.

In conclusion, ginsenoside $\operatorname{Rg} 1$ can inhibit the senescence of D-gal-induced VSMCs, which may be related to its partial inhibition of $\mathrm{p} 16^{\mathrm{INK} 4 \mathrm{a}} / \mathrm{Rb}$ and $\mathrm{p} 53-\mathrm{p} 21^{\mathrm{Cip} 1 / \text { Wafl }}$ signaling pathways during cell cycle progression. Many factors are involved in cell senescence. In this study, changes in cellular ultrastructure, cell cycle, and p16, p21 and p53 protein expression were examined. Other factors, including mRNA expression, should be investigated in further studies.

\section{Conflicts of interest}

The authors declare no conflict of interest.

\section{ACKNOWLEDGMENTS}

Research supported by the Hubei Provincial Natural Science Foundation (\#2013CFB390) and the Science Research Projects of Hubei Provincial Department of Education (\#B20121301).

\section{REFERENCES}

Beauséjour CM, Krtolica A, Galimi F, Narita M, et al. (2003). Reversal of human cellular senescence: roles of the p53 and p16 pathways. EMBO J. 22: 4212-4222. http://dx.doi.org/10.1093/emboj/cdg417

Bianchessi V, Badi I, Bertolotti M, Nigro P, et al. (2015). The mitochondrial lncRNA ASncmtRNA-2 is induced in aging and replicative senescence in Endothelial Cells. J. Mol. Cell. Cardiol. 81: 62-70. http://dx.doi.org/10.1016/j. yimcc.2015.01.012

Capparelli C, Chiavarina B, Whitaker-Menezes D, Pestell TG, et al. (2012). CDK inhibitors (p16/p19/p21) induce senescence and autophagy in cancer-associated fibroblasts, "fueling" tumor growth via paracrine interactions, without an increase in neo-angiogenesis. Cell Cycle 11: 3599-3610. http://dx.doi.org/10.4161/cc.21884

Cheung TM, Yan JB, Fu JJ, Huang J, et al. (2015). Endothelial cell senescence increases traction forces due to ageassociated changes in the glycocalyx and SIRT1. Cell. Mol. Bioeng. 8: 63-75.http://dx.doi.org/10.1007/s12195-014$\underline{0371-6}$

Debacq-Chainiaux F, Erusalimsky JD, Campisi J and Toussaint O (2009). Protocols to detect senescence-associated betagalactosidase (SA-betagal) activity, a biomarker of senescent cells in culture and in vivo. Nat. Protoc. 4: 1798-1806. http://dx.doi.org/10.1038/nprot.2009.191

Dimri GP, Lee X, Basile G, Acosta M, et al. (1995). A biomarker that identifies senescent human cells in culture and in aging skin in vivo. Proc. Natl. Acad. Sci. USA 92: 9363-9367. http://dx.doi.org/10.1073/pnas.92.20.9363

Fenouille N, Robert G, Tichet M, Puissant A, et al. (2011). The p53/p21Cip1/Waf1 pathway mediates the effects of SPARC on melanoma cell cycle progression. Pigment Cell Melanoma Res. 24: 219-232. http://dx.doi.org/10.1111/ j.1755-148X.2010.00790.x

Gorenne I, Kavurma M, Scott S and Bennett M (2006). Vascular smooth muscle cell senescence in atherosclerosis. Cardiovasc. Res. 72: 9-17.http://dx.doi.org/10.1016/j.cardiores.2006.06.004

Han XL, Wu FG, Zhang ZY and Tong TJ (2007). Posttranscriptional induction of p21Waf1 mediated by ectopic p16INK4 in human diploid fibroblast. Chin. Med. J. 120: 405-409.

Krishnamurthy J, Torrice C, Ramsey MR, Kovalev GI, et al. (2004). Ink4a/Arf expression is a biomarker of aging. J. Clin. Invest. 114: 1299-1307.http://dx.doi.org/10.1172/JCI22475

LaPak KM and Burd CE (2014). The molecular balancing act of p16(INK4a) in cancer and aging. Mol. Cancer Res. 12: 167-183.http://dx.doi.org/10.1158/1541-7786.MCR-13-0350

Leontieva OV and Blagosklonny MV (2013). CDK4/6-inhibiting drug substitutes for p21 and p16 in senescence: duration of cell cycle arrest and MTOR activity determine geroconversion. Cell Cycle 12: 3063-3069. http://dx.doi. org $/ 10.4161 / \mathrm{cc} .26130$

Genetics and Molecular Research 15 (3): gmr.15038409 
Li CP, Zhang MS, Liu J, Geng S, et al. (2014). Research of anti-aging mechanism of ginsenoside Rg1 on brain. Zhongguo Zhongyao Zazhi 39: 4442-4447.

Liu PH, Tong TJ and Zhang ZY (2001). Zhonghua Lao Nian Yi Xue Za Zhi 20: 128-131.

Sikora E, Arendt T, Bennett M and Narita M (2011). Impact of cellular senescence signature on ageing research. Ageing Res. Rev. 10: 146-152.http://dx.doi.org/10.1016/j.arr.2010.10.002

Tane S, Ikenishi A, Okayama H, Iwamoto N, et al. (2014). CDK inhibitors, p21(Cip1) and p27(Kip1), participate in cell cycle exit of mammalian cardiomyocytes. Biochem. Biophys. Res. Commun. 443: 1105-1109. http://dx.doi. org/10.1016/j.bbrc.2013.12.109

Tian Y (2014). Medical Cell Biology. 3rd edn. Beijing, People's Health Press, 231-247.

Wang XD, Gu TX, Shi EY, Lu CM, et al. (2010). Effect and mechanism of panaxoside Rg1 on neovascularization in myocardial infarction rats. Chin. J. Integr. Med. 16: 162-166. http://dx.doi.org/10.1007/s11655-010-0162-4

Wen DZ, Qu JB, Shi Z, Bao XY, et al. (2005). Effect of Sanqi saponin Rg1 against senescence of astrocyte in D-galactose induced senescence mice model. Chin. J. Neuroanat. 21: 667-670.

Xi H, Li C, Ren F, Zhang H, et al. (2013). Telomere, aging and age-related diseases. Aging Clin. Exp. Res. 25: 139-146. http://dx.doi.org/10.1007/s40520-013-0021-1

Yue Z, Rong J, Ping W, Bing Y, et al. (2014). Gene expression of the p16(INK4a)-Rb and p19(Arf)-p53-p21(Cip/Waf1) signaling pathways in the regulation of hematopoietic stem cell aging by ginsenoside Rg1. Genet. Mol. Res. 13: 10086-10096. http://dx.doi.org/10.4238/2014.December.4.3

Genetics and Molecular Research 15 (3): gmr.15038409 